\title{
Engineering Students' Perceptions when Working with Narratives in a Humanities Course
}

\author{
Edgardo Leopoldo Maza-Ortega \\ Universidad del Bío Bío, Chile \\ Carmen Cecilia Espinoza-Melo \\ Universidad Católica de la Santísima Concepción, Chile
}

\begin{abstract}
This research reveals the change that occurs in a university course when using narratives, which allows facing monumentalism in the classrooms, considering that, in most of them, classes are still being held in a traditional way without taking into account what the students think about the topics covered in the courses. The research is within the qualitative method. The results obtained allow to establish the influence of the course on the learning strategies used by the students, as stable learning indicators, two networks are presented: one corresponding to the use of narratives, and the second, incorporation of the question. Students are motivated to work collaboratively and have a favorable opinion of implementation.
\end{abstract}

Keywords: narratives, engineer training, humanities education, collaborative work, qualitative research.

\section{Introduction}

The importance of complementary training in engineering studies has been recognized in most of the world's universities, and traditionally, it has been covered by requiring one, two or three subjects that deal with specific topics of humanism (Belandría, 2011. p.17)

Likewise, some students state that they lack interest or vocation for these subjects. Obviously, the consequence of this situation is apathy, a reluctance for humanism and a deep immersion of the students in the realm of mathematics, physics, chemistry and engineering techniques. (Belandría, 2011. p.18)

Likewise, the field of action of the engineer is not related only to the scientific and technological, but is immersed in a complex reality that he must understand and know in its entirety to optimize the exercise of his profession based on the integral well-being of society and the natural environment where he develops. This requires knowing the 
society and the environment that it transforms, understanding its cultural and natural diversity, being aware of the needs of the human being and for this he needs to be sensitive and aware of his social function as a person, as an engineer and as an agent of progress, change and development (Belandría, 2011. p.18)

According to the Organization for Economic Cooperation and Development (OECD), a large number of Chileans (53\% of adults, but $84 \%$ of the country) do not understand what they read, thus they become functionally illiterate, moving away from the understanding of their social, cultural and historical environment. This is not new or local, on the contrary, it has been happening in different countries for at least thirty years. Today, prominent economists, such as the Spanish Joan Antoni Melé, propose concepts such as "ethical banking" or Edmund S. Phelps, Nobel Prize in Economics, quoted by Nuccio Ordine (2018) says:

(...) Today economies lack the spirit of innovation. Not only do labor markets need more technical skills, they require an increasing number of soft skills, such as the ability to think imaginatively, to come up with creative solutions to complex challenges, and to adapt to changing circumstances and new constraints. (...) A necessary first step is to reintroduce humanistic subjects in schools and in university curricula. The study of literature, philosophy and history will inspire young people to seek a fulfilling life, a life that includes making creative and innovative contributions to society. (p. 23)

Certainly, knowledge of history will make people better understand how society has arrived at the present moment. Experiencing the feelings and teachings of literature and the arts will make citizens more aware and sensitive to reflect on the decisions to be made, as opposed to the excessive use of reason, which can lead to misleading the correct direction of that society. Possessing knowledge of philosophy will make society develop fundamental critical thinking that will help choose the path to the destiny of the country.

In The Utility of the Useless, Nuccio Ordine speaks of the marginalization of the humanities in this technological age, highlights the importance of the humanities in the training of citizens and criticizes the commercial use that has been made of education. These areas (literature, philosophy, history) have a value in themselves and are decisive in our human and civic education, or in the development of our critical and at the same time compassionate thinking, capable of keeping that humanity in mind, and that it implies being the same and different. In many universities, from different countries, the idea that these, only, should work with mercantilist principles and should be oriented with the postulates of profitability, effectiveness, efficiency and competitiveness typical of the market economy has been installed. Ordine expresses concern that students are considered clients, and since the client is always right, the quality of teaching suffers in favor of the speed with which a degree is sought. On the other hand, according to Terry Eagleton (2017):

Academic institutions, in the past areas of critical reflection, are being increasingly reduced to market bodies (...). For the most part, they are in the hands of technocrats 
(...). The work of the new intellectual proletariat of academics is evaluated according to whether their lectures on Plato or Copernicus help to stimulate the economy. (p. 169)

Nothing could be more wrong, according to Nuccio Ordine (2018), when he talks about humanistic knowledge or those that do not produce an immediate economic benefit. "These are an end in themselves since they can play a fundamental role in the cultivation of the spirit and in the civil and cultural development of humanity." (p. 9)

\section{Theoretical framework}

Why the humanities serve today more than ever, with regard to technology today and in Heidegger, is because the latter is the representation of society. This society that bases its development on technique, this same technique that is part of consumption to sustain the economy. The conjunction of technique and economics lead to solidify a way of distracting attention from how important it is to be aware of the reality and the immediate social environment of people. The humanities help to understand the above to form a solid foundation for critical thinking.

According to Martha Nussbaum, cited by Adriana Valdés (2017), "treating people as manipulable objects if they have never learned another way of looking at them" is the basis of the inequality of a society like ours. A society in democracy is difficult to be thought of if citizens are not "capable of thinking for themselves, criticizing tradition, and understanding the meaning of other people's sufferings and achievements." Likewise, "(...) generations of utility machines will begin to be produced, instead of comprehensive citizens" (Valdés, 2017). The same could be thought of the educational reforms of secondary education where the government tried to eliminate philosophy, history and the arts, at some point in Chile. When there is little or no critical or reflective thinking, as Adriana Valdés puts it, the sense of what the country wants to achieve is lost, part of the citizenry begins to feel exploited and excluded. In this way, people become useful in the manner of Heidegger (Acevedo, 2016). The utensil, the human being in this case, remained unthemed by deception, or fear, thus remaining at the hand of the system for decades, both at the beginning of the republic and throughout the twentieth century. In the same way, the person is "provoked" and transformed into a resource even though it is not, but it becomes quantifiable. Without going any further, companies still maintain their Human Resources departments today. Some recently began to call their workers collaborators, thus forming a respectional totality. When all the above happens, without realizing it, Byung Chul-Han's statement, "Now you exploit yourself and believe you are realizing yourself," makes perfect sense. For these reasons it is that humanistic knowledge is for life and not instrumental, temporary, as are some skills that have been learned and then discarded due to their obsolescence over time, an example of the above is the learning of computational languages that a user had to have to operate a computer, before the appearance of the Windows operating system. According to Ordine (2018), knowledge, humanistic for our interest, is the only form of "wealth" that does not diminish or lose when it is given and, on the contrary, it does enrich the recipient for life. 
The fact that people always experience crises is a fundamental reason to study the humanities. We exemplify this, in general, with engineers who throughout their lives make decisions based on the quantitative; However, when all the goals are fulfilled as family, home, car and midlife approaches, some begin to wonder what the meaning of all this has been, feeling enslaved to work and the responsibilities of life. It is when the midlife crisis can appear. The humanities are the way that leads to the answers and that solves such uncertainties and questions by finding in them those answers that are not quantitative, but qualitative. Literature gives some examples that transpose time such as Hamlet and his vital doubt of taking revenge, or not on her mother and uncle for the death of her father, the king of Denmark or Faust selling his soul to the devil for the success that did not arrive. How useful it is to read these texts to realize that literature contains this knowledge that has no immediate economic value, but that helps people understand vital issues in times of crisis.

Other types of crises, such as social ones, have been present throughout the history of humanity. Some of them recent, in Chile, such as the social issue of the nitrate companies at the beginning of the last century, with all that it meant between abuses and deaths of men, women and children. Then Luis Emilio Recabarren (2010), in his speech "The Rich and the Poor Through a Century of Republican Life", in Rengo on September 3, 1910, diagnoses the situation of Chilean workers when celebrating the centenary of the republic and where he says that the workers, one hundred years after the republic, have nothing to celebrate. That is why, for him, it was so important that workers know how to read:

To promote instruction, in all its degrees and in all its forms, is the duty of every person who considers himself civilized. Encouraging education, as has been said, is to weaken the foundations of unpredictability and vice; it is to initiate his disappearance ... Let us encourage him to read, to think, to analyze. Doing this, (...) is leading the people to improve their living conditions. The most educated people will be the most powerful people. (p. 55)

In an interview, Howard Gardner (2016) says:

(...) And it is one of the reasons for the crisis of maturity, when they realize that there are no (...) humanistic studies: Philosophy, Literature, History of Thought (...). You can live without philosophy, but worse. In an experiment with MIT engineers, we discovered that those who had not studied humanities, when they reached their 40s and 50s, were more likely to suffer crises and depressions (...). Because engineering and technological studies end up giving you a feeling of control over your life, in the end, unreal: you only focus on what has a solution and on the questions with answers. And for years you find them. But, when with maturity you discover that it is impossible to control everything, you become disoriented (...) due to lack of humanistic studies.

Training in the humanities allows promoting reflection in people, producing an internal change in them. This also allows a personal reflection to make a generational comparison 
between the present generation and their parents or grandparents. Likewise, with the evolution of society, allowing a reflection on it and how they will develop in their work environment, for example, to help improve society. This reflection gives all people the opportunity to share and realize that they have common ideas. Morin (1999), raises the need:

(...) for the education of the future, of a great relationship of the knowledge resulting from the natural sciences in order to locate the human condition in the world, of those resulting from the human sciences to clarify the multidimensionalities and human complexities and the need to integrate the invaluable contribution of the humanities, not only of philosophy and history, but also of literature, poetry, the arts (...). (p. 22).

Adela Cortina (2018) adds an ethical factor to humanities training when she points out:

The question is not, then, in schools and universities to train only well-specialized technicians who can compete and meet the demands of the markets, whatever they may be, but to educate good citizens and good professionals, who know how to use the techniques to implement them at the service of good ends, who take responsibility for the means and the consequences of their actions in order to achieve the best ends. (pp. 134-135)

In some relation to this, the only thing we are clear about going forward is that society as a whole will change, be it in technology, education, jobs or historical processes, therefore the last thing that education should do is deliver more information to students, they already have a lot (Harari, 2018). What they will need is the ability to decide between what is more or less important, it is in these circumstances where the professional person of the future will need a solid humanistic training that allows them to have the tools that enable them to make better decisions, both in terms of personal as well as professional. Harari himself states that:

The decisions we make in the coming decades will shape the future of life itself, and we can make these decisions only from our current world view. If this generation lacks a complete conception about it, the future of life will be decided at random. (pp 287-288)

\section{Methodology}

A qualitative research was carried out, which is guided by significant areas or research topics. Ander-Egg (2011) defines the concept of research as "a reflective, systematic, controlled and critical procedure that aims to discover or interpret the facts and phenomena, relationships and laws of a certain area of reality" (p.18). Within which questionnaires and narrative diaries were used, through the latter, the data of this research were taken, so that the students could express their appreciations of their state before and after taking humanities subjects from the curriculum of their career.

Narratives were used to collect data which sought to gather information about the course, which aspect was the most relevant for students when learning humanities, for 
example. The narratives of the students delivered throughout the semester were analyzed. Data analysis was carried out with the qualitative software Atlas.Ti 7.0.

Narratives in education are used as a didactic resource, in this way the conception of an education that is limited to the memorization of information and its retention is combined, where the student is motivated to learn new knowledge in a different way (Tapia, 2019).

The notion that mediates the narrative perspective is that of listening to the voice of the subjects, understood as that which is the bearer of life history (Arévalo, Fernández, Hidalgo, Lepe, Miranda, Nuñez and Reyez, 2016. p. 225)

\section{Results}

To begin with the narratives, a coding was carried out and then organized and grouped into categories according to the main topic of the research, which allowed to develop an interpretation and synthesis of the information found in the narratives. The categories were raised once the narratives were applied to the participants of the experience.

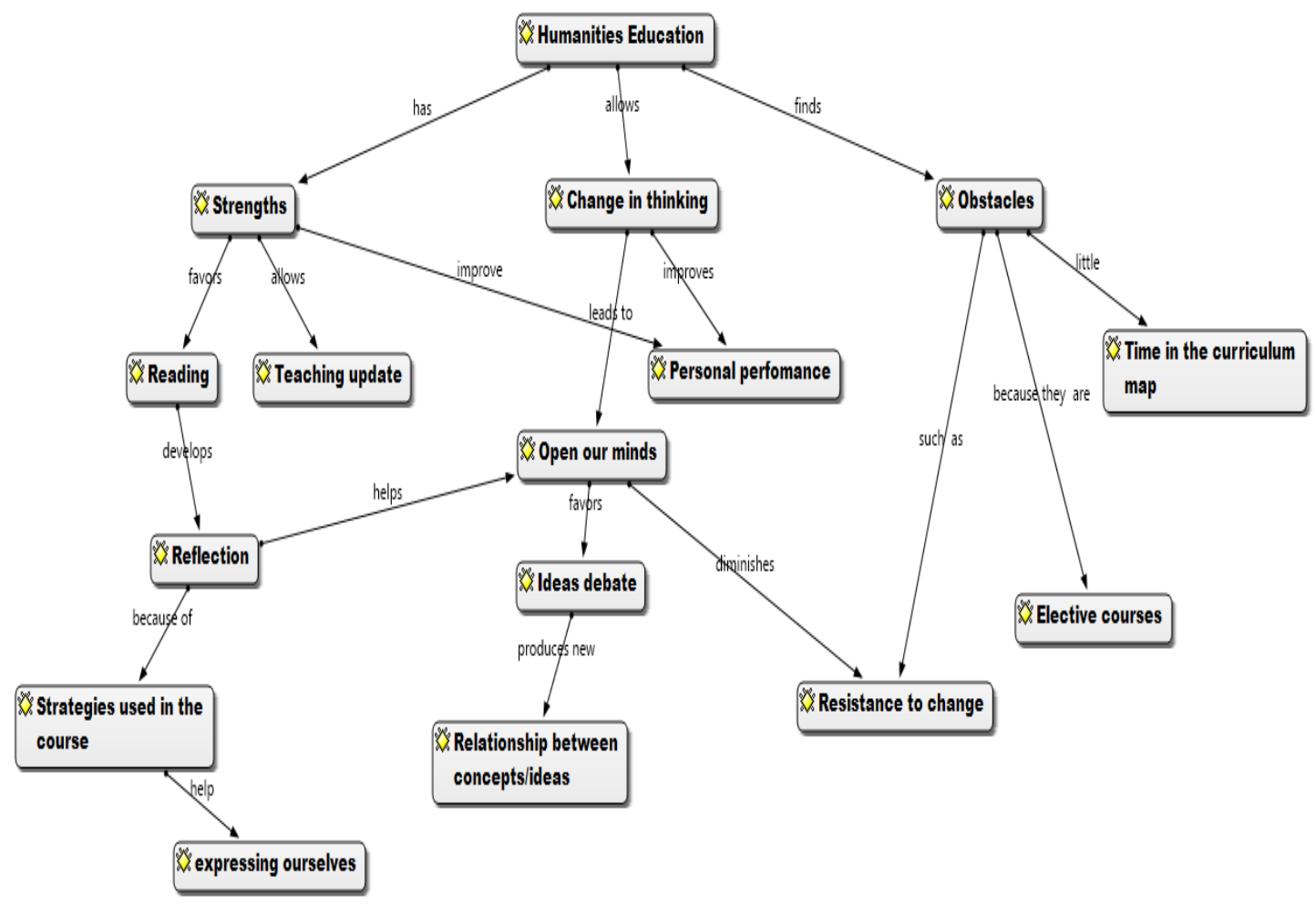

Figure 1. Humanities Education semantic network

Figure 1 shows the semantic network called Education in Humanities in which three subcategories can be seen, the first called Strengths, it is observed that humanities 
training favors reading in students, allows them to reflect on his practice, to be able to express himself. In addition, the strategies used in the course facilitate teaching and it is given in a more contextualized way.

It is observed, in the second subcategory called Way of Thinking, how students are able to open their minds to other topics proposed in class, discuss ideas and relate concepts. There is also the third subcategory called Obstacles, where, due to the information provided by the students, one of the drawbacks is that the humanities are very little valued in the training of engineers, there are no compulsory humanities courses, the Humanities courses are very little valued by students too, they prefer to take other subjects.

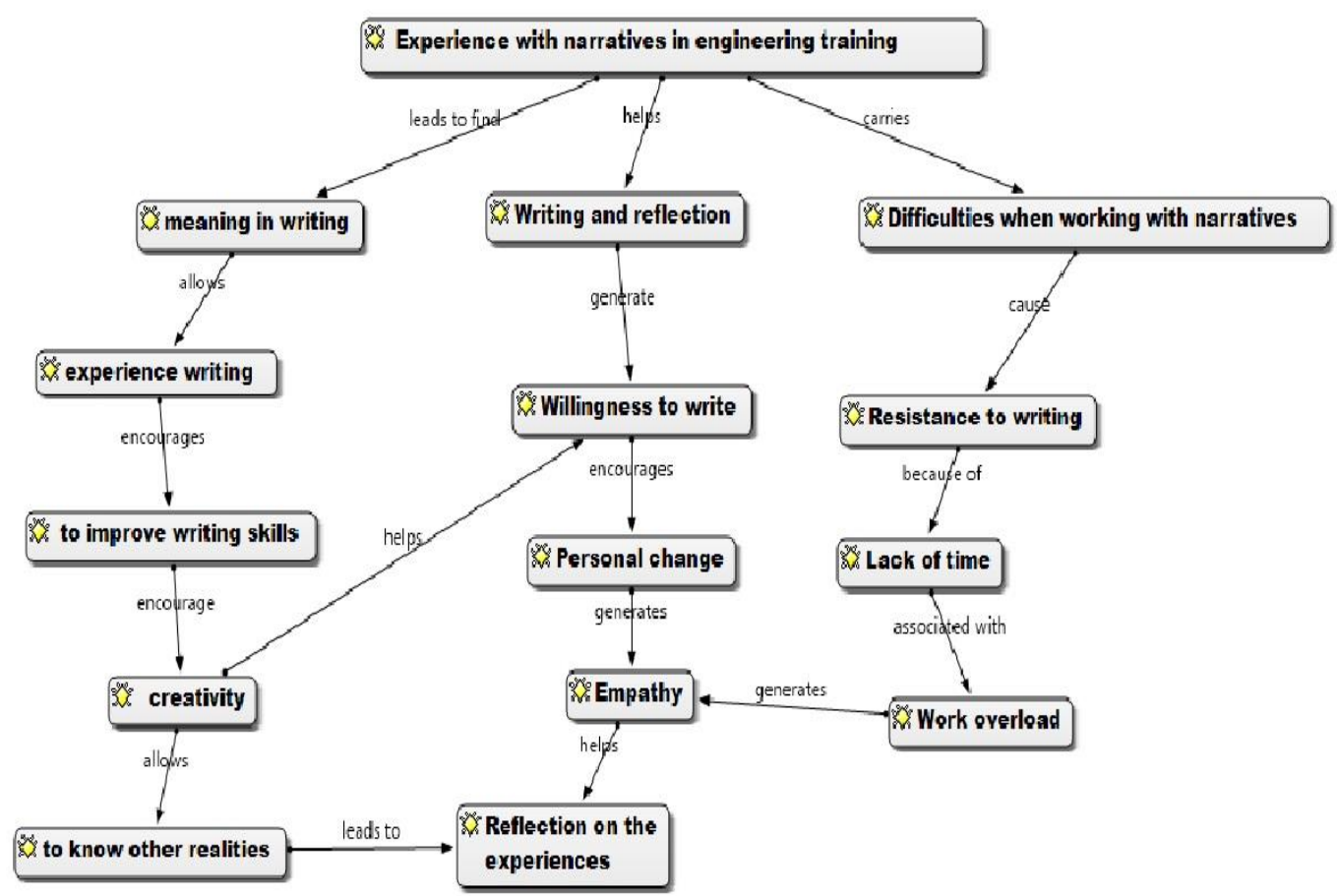

Figure 2. Semantic network Experience with narratives in engineering training.

Figure 2 shows the semantic network corresponding to experiences with narratives in the training of engineers, it is composed of three subcategories. The first subcategory is called Meaning of Writing, here we find how writing influences students and the benefits that it brings them in their training, increasing their creativity, allowing them to know other realities.

The second subcategory is called Writing and Reflection, here we obtain how students present a willingness to write and realize that this is a tool that allows them to achieve 
changes in society, since they can put themselves in the place of the other and better understand reality, leading them to reflect on the situations they have experienced.

The third subcategory is called Difficulties when working with narratives, where we find the resistance of students towards writing, since they insist that they have very little time to carry out this activity, in addition to an overload of work.

\section{Conclusions}

It can be observed, through the interviews applied to the course participants, that working with narratives is a learning experience that allows to modify the work in the classroom and that favors knowing other ways of delivering the contents. This helped to increase communication within the work groups, foster responsibility among students, with a greater bonding of students, as a result of the knowledge generated between them, they also recognized the ability to incorporate changes during the development of classes, being able to respond to emerging situations.

This research will continue in the future with a quantitative component, where a questionnaire will be built, to expand it to a mixed research.

Finally, everything that makes them more human and that will contribute to the different capacities of the future professional person. Likewise, the teaching of the humanities, at the university level, would allow students to relate different aspects that influence decision-making in the various areas of their lives. The above to have, in the end, not only a specialist who makes better decisions, but an integral person, aware of his/her social, historical, cultural environment and with instrumental knowledge for life, at the same time.

\section{References}

[1] Acevedo Guerra, J. (2016). Heidegger y la época técnica. Santiago. Chile. Editorial Universitaria.Ander-Egg, E. (2011). Aprender a Investigar. Nociones básicas para la investigación social. Córdoba. Argentina. Editorial Brujas.

[2] Arévalo, A., Fernández Ll, B., Hidalgo, F., Lepe, Y., Miranda, C., Núñez, M., \& Reyes, L. (2016). Corporalidades y narrativas docentes: un dispositivo metodológico para la investigación y formación de profesores. Estudios pedagógicos (Valdivia), 42(4), 223-242. Recuperado de :

[3] https://scielo.conicyt.cl/scielo.php?pid=S071807052016000500013\&script=sci_arttext\&tlng=e

[4] Belandria, J.(2011). Importancia de la formación humanística, ecológica, social y ética en los estudios de ingeniería. Ciencia e Ingeniería, 32(1),17-23. ISSN: 13167081.

Recuperado

de: https://www.redalyc.org/articulo.oa?id=5075/507550790004 
[5] Cortina, A. (2018). La Ética. ¿Para qué sirve realmente...? Barcelona. España. Paidós.

[6] Eagleton, T. (2016). Cultura. Barcelona. España. Taurus.

[7] Gardner, H. La vanguardia. (2019, 30 de diciembre). Una mala persona no llega nunca a ser buen profesional. Argentina. Fasgo. Recuperado de

[8] http://www.fasgo.org.ar/images/Una_mala_persona_Profesional.pdf

[9] Harari, Y.N. (2018). 21 lecciones para el siglo XXI. Santiago. Chile. Debate.

[10] Morín, E. (1999). Los siete saberes necesarios para la educación del futuro. Paris. Francia. UNESCO.

[11] Nussbaum, M. (2010). Sin fines de lucro. Por qué la democracia necesita de las humanidades. Buenos Aires. Argentina. Katz editores.

[12] Ordine, N (2018). La utilidad de lo inútil. Manifiesto. Barcelona. España. Acantilado.

[13] Ordine, N. (2018). Una escuela para la vida. Valparaíso. Chile. Editorial Universidad de Valparaíso.

[14] Recabarren, L. (2010). Ricos y pobres. Santiago. Chile. Lom ediciones.

[15] Tapia, J. L. (2019). Uso de narrativas digitales como recurso didáctico para el aprendizaje adulto: propuesta de diseño para su integración en el aprendizaje permanente. 593 Digital Publisher CEIT, 4(4), 29-43. Recuperado de :

[16] https://doi.org/10.33386/593dp.2019.4.114

[17] Valdés, A. (2017). Redefinir lo humano: las humanidades en el siglo XXI. Valparaíso. Chile. Editorial Universidad de Valparaíso.

[18] Belandria, José (2011). Importancia de la formación humanística, ecológica, social y ética en los estudios de ingeniería. Ciencia e Ingeniería, 32(1),1723.[fecha de Consulta 4 de Noviembre de 2020]. ISSN: 1316-7081. Disponible en: https://www.redalyc.org/articulo.oa?id=5075/507550790004 